\title{
THE IDSE AND OTHER STORIES
}




\section{$\mathbf{R}$}

The Russian Library at Columbia University Press publishes an expansive selection of Russian literature in English translation, concentrating on works previously unavailable in English and those ripe for new translations. Works of premodern, modern, and contemporary literature are featured, including recent writing. The series seeks to demonstrate the breadth, surprising variety, and global importance of the Russian literary tradition and includes not only novels but also short stories, plays, poetry, memoirs, creative nonfiction, and works of mixed or fluid genre.

Editorial Board:

Vsevolod Bagno

Dmitry Bak

Rosamund Bartlett

Caryl Emerson

Peter B. Kaufman

Mark Lipovetsky

Oliver Ready

Stephanie Sandler

For a list of books in the series, see page 339 


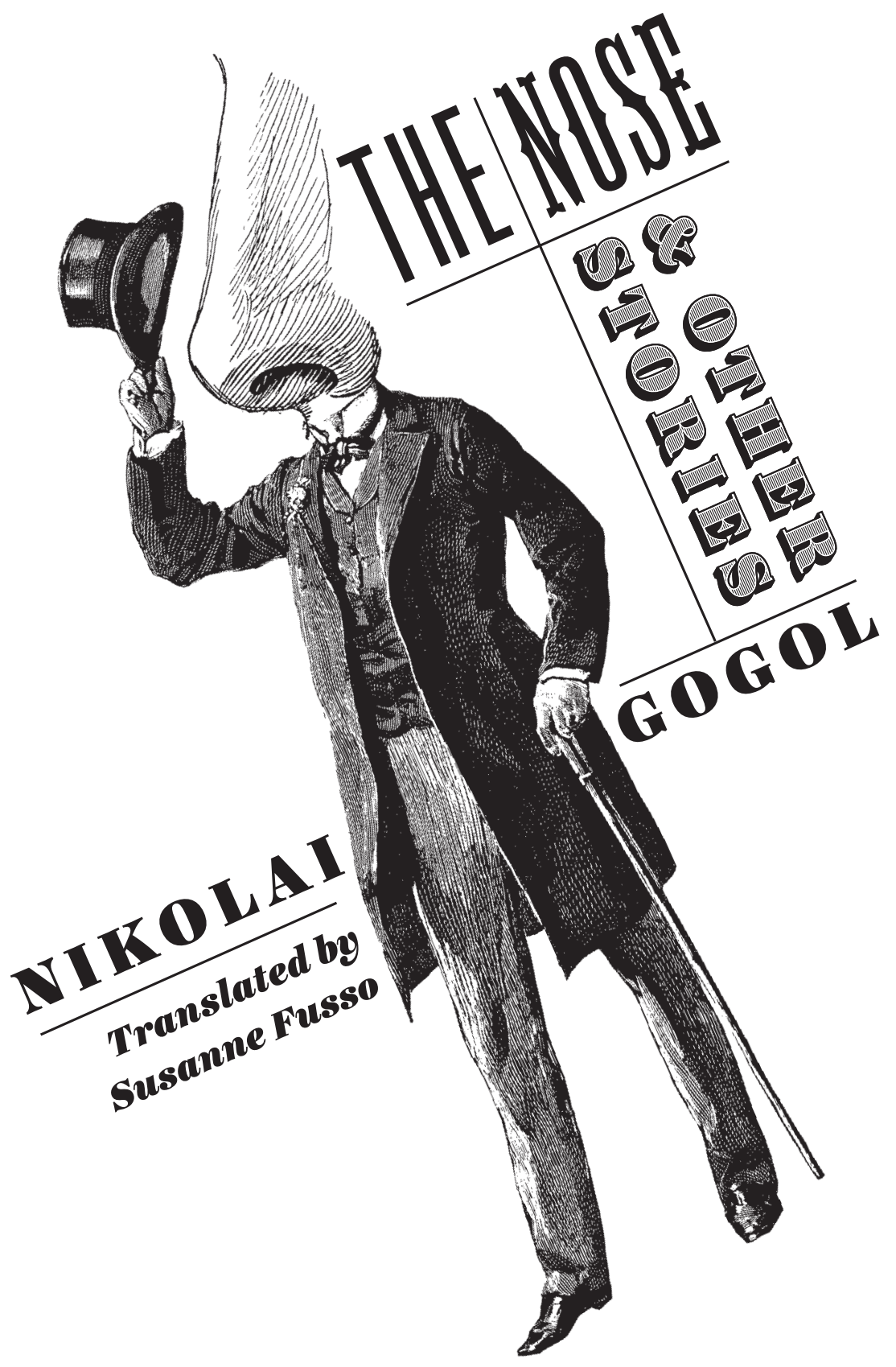

Columbia University Press / New York 
Published with the support of Read Russia, Inc., and the Institute of Literary Translation, Russia

Columbia University Press

Publishers Since 1893

New York Chichester, West Sussex

cup.columbia.edu

Translation copyright $\left(C_{0} 2020\right.$ Susanne Fusso

All rights reserved

Library of Congress Cataloging-in-Publication Data

Names: Gogol', Nikolaĭ Vasil'evich, 1809-1852, author. | Fusso, Susanne, translator.

Title: The nose and other stories / Nikolai Gogol ; translated by Susanne Fusso.

Description: New York : Columbia University Press, [2020] | Series: The Russian Library | Translated from the Russian. Identifiers: LCCN 2019053937 (print) | LCCN 2019053938 (ebook) | ISBN 9780231190688 (cloth ; acid-free paper) | ISBN 9780231190695 (paperback ; acid-free paper) | ISBN 9780231549066 (ebook)

Classification: LCC PG3333 .A6 2020 (print) | LCC PG3333 (ebook) | DDC $891.73 / 3-\mathrm{dc} 23$

LC record available at https://lccn.loc.gov/2019053937

LC ebook record available at https://1ccn.loc.gov/2019053938

Columbia University Press books are printed on permanent and durable acid-free paper.

Printed in the United States of America

Cover design: Roberto de Vicq de Cumptich

Book design: Lisa Hamm 
For Joe

$x$ 
